\title{
Applying Heuristic Evaluation for Evaluate and Gain Perspective of Online Transportation: A Case Study
}

\author{
Pristi Sukmasetya $^{1 *}$, Muhammad Kholid Shalahuddin ${ }^{2}$
}

\begin{abstract}
${ }^{1}$ Department of Informatics Engineering, Universitas Muhammadiyah Magelang, Magelang, Indonesia.
${ }^{2}$ Student of Informatics Engineering Department, Universitas Muhammadiyah Magelang, Magelang, Indonesia. *Corresponding author. Email: pristi.sukmasetya@ummgl.ac.id
\end{abstract}

\begin{abstract}
E-transportation gave rise to a business and is currently developing, namely the business of transportation. In Indonesia the use of online transportation such as Go-Jek has been done a lot. The user interface or application display will more or less influence the user in using the application. This study focuses on analyzing the user interface and application user experience using the Heuristic Evaluation (HE) method. From the results obtained, it can be concluded that the application of Go-jek is considered to have fulfilled almost the nine variables of the existing heuristic evaluation. of the ninth, respondents stated that this application excels on five variables, i.e. match between system and the real world, recognition rather than recall, flexibility and efficiency of use, aesthetic and minimalist design, help user recognize-diagnose-recover from errors. This research is enough to prove that an application with a good user interface will certainly make the user experience more enjoyable when using the application.

Keywords: Heuristic Evaluation, online transportation, user interface
\end{abstract}

\section{INTRODUCTION}

In the era of globalization, technology is widely used to help daily activities. Especially in information technology, because with the development of information technology (IT) daily activities can be carried out efficiently, effectively and accurately, so as to increase productivity. IT does not only focus on computer technology that is used to process and store information, but also in communication technology to send information [1]In its development known as the industrial revolution, and according to the European Parliamentary Research Service the industrial revolution has occurred four times. Even Japan has entered the era of society 5.0 [2] which has a definition of "A human-centered society that balances economic advancement with the resolution of social problems by a system that highly integrates cyberspace and physical space" [2].

In Indonesia itself now has entered the industrial revolution 4.0, where all the needs related to technology and the internet in all fields. The development of technology has triggered the birth of electronic-life which means that all activities are dependent on electronics. Some of the activities include e-commerce, e-education, e-journal, etransportation and many more [3]. The development of information technology along with the internet triggered elife to develop rapidly [4]. In e-transportation in particular, this activity presents transportation services that are online and application-based where the internet is very influential in this regard. E-transportation gave rise to a business and is currently developing, namely the business of transportation services with motorbikes commonly known as motorcycle taxis. If in the past in terms of ordering and payment still using conventional methods now with the help of technology and the internet all can be done online. Or better known as an online motorcycle taxi [5]. Online transportation emerged by overcoming the problems of a poor transportation system [6]Several companies have formed services and applications for online transportation. Among them are Go-jek, Grab, and Uber. Online transportation applications have attractive advantages including providing convenience, low cost, convenience, guaranteed security, and can even reduce congestion. Even the development of online transportation application companies has increasingly penetrated into various fields, not only as a motorcycle taxi but can be as a courier in delivering goods [7]

Go-jek is one of the first application that focus on transportation application in Indonesia. Founded in 2011 by Nadiem. Nadiem founded Go-jek, a mobile-based motorcycle taxi or shuttle service. Not only two-wheeled vehicles but also vehicles. This application allows users to order online for this service. Go-jek in his service is very professional and modern. Drivers are equipped with android-based mobile phones to support communication with users and with the best route in delivering passengers. Not just shuttle but Go-jek also penetrated the field of food (Go-food), courier (Go-Send) and much more. The participation of users is a major factor in the development and improvement of an application [5].

An evaluation of the application is required by the end user to get more satisfaction with the application. Development focuses on the capabilities of users using the application to see satisfaction with the user interface and user experience. Interface design (user interface) and user experience (user experience) are the main factors of the problems that are often faced by application or web developers. There are five methods that are often used, namely, Cognitive WalkThrough, Heuristic Evaluation, Variants of Heuristic Evaluation, Pluralistic Walk-Through [8], and Perspective- 
Based Inspection [9]. In this research to evaluate the Go-jek application, the Heuristic Evaluation (HE) will be held to evaluate and gaining more insight about perspective of user with the online transportation application itself. This research that uses a similar method to the web or application has been done before in the microscopic academic portal system using the Heuristic Evaluation method [10]. Based on the above reasons, it is necessary to know the satisfaction of Go-jek users to assess usability in the application. For that reason, we try to analyze the user interface and user experience of the application using the Heuristic Evaluation (HE) method.

\section{RELATED WORK}

\subsection{User Interface}

User interface or in Indonesian Interface is a communication activity between users and systems. The user interface will provide information in navigating directions to find a compilation solution for finding information[11]. In a study conducted at Stie Putra Nation for the evaluation of the User Interface (UI) on an academic information system, with the User Centered System Design method with various variables that are sources of improvement for the UI. With the design prototype produced from this research will be a reference for the development of Academic Information Systems applications on their UI [12][6].

In another study entitled "Testing Usability User Interface Users and Users of Hypertext Based E-Reader Applications" using the SUS method. Which developed the hypertext-based thesis E-Reader application from Widyatama University, resulting in a user interface design and user experience with a high level of acceptability so that it is easily accepted and used by users. And compiled by comparison with UAD's Digilib, this E-Reader gets a significant level of usability and is getting higher [13].

Another study for the user interface is the application of the community service Term Joyoboyo Kediri Police. With the Eight Golden Rule method, the application from the Kediri Regional Police gets a value of $60 \%$ where the value meets the application criteria. And with this research it yields to the application user interface in the Mockup section in the figure [14].

\subsection{Heuristic Evaluation}

Research related to the heuristic evaluation (HE) method, entitled "Analysis of Usability on the Undiskha Website Using the Heuristic Evaluation Method" [24] yields reasonable usability criteria. With respondents from the lecturers totaling 176 lecturers and 385 students, out of the 10 variables used in the HE method resulted in a high level of usability for lecturers of $63 \%$, and for students in the medium category with a percentage of $50 \%$. From all the evidence it can be concluded that the Undiskha website is able to meet the usability criteria. From the HE method, the improvement on the appearance and function of the website, while from the HE questionnaire, it gave rise to the idea to emphasize improvements to the SOP for information services.

Another study on the EzySchool application where the application is used for parents in controlling their children at school. In the user interface is quite good, it needs to be evaluated so that aspects of the user experience are achieved properly. Heuristic evaluation (HE) method is used which uses the expert evaluator's method. So that it can find problems with usability and can be solved by the HE method. A total of 17 problems involving only 3 evaluators can be a reference to find solutions in designing designs [15] Jawa Timur Park Group provides services and facilities through its website, jawatimurparkgroup.com is the official website of Jatim Park. And to find the comfort of a website requires usability aspects with heuristic evaluation (HE) evaluation methods. In this study two stages of evaluation were used, the first stage produced 34 problems and then after the improvement was made the second evaluation and showed a decrease to 17 problems. By using HE we can minimize the problem of usability [1][16].

\section{METHOD}

\subsection{Research Method}

This paper used heuristic evaluation to evaluate and gaining the insight of the online transportation application's trend. In this case we focus on one online transportation application, Gojek. Heuristic Evaluation is one of kind engineering method that focus on usability and developed by Jackob Nielsen in 1994[11][17]. It states that the evaluation framework to find the problems in user interface design. This can help the design process does not repeat by requiring a number of assessors to investigate and make decisions in the user interface, based on the evaluator's experience of adhering to accepted usage principles. Assessment methods can be done since early in the application development process [18][9]. There're nine variable of heuristic evaluation that have been used here. There is visibility of system status, match between system and the real world, user control and freedom, error prevention, recognition rather than recall, flexibility and efficiency of use, aesthetic and minimalist design, help user recognize-diagnose-recover from errors, the last was help and documentation.

\subsection{Data Collection}

The study was conducted with preparing ten list of variables of Heuristic Evaluation and change it into question that will be answered by the respondent. The question itself is a open question and distributed with google form in three weeks. The minimum requirements for being a respondent are Gojek application users and at least they have used the application for a month, and at least only five until seven persons so we can check their experience using the 
Table 2 Checklist Result from Heuristic Evaluation application. We also invite three usability inspectors two of which were experts while the other two were novice. These experts will assets the result from the respondent and processing those data into some insight that can help understanding the trend of this online transportation. The object for this research focus on Go-jek application.

\subsection{Data Analysis}

In this step we use qualitative analysis to gain the user perspective about the application itself. We use Jackob Nielsen's variable in heuristic evaluation which contains of ten variables. There is visibility of system status, match between system and the real world, user control and freedom, error prevention, recognition rather than recall, flexibility and efficiency of use, aesthetic and minimalist design, help user recognize-diagnose-recover from errors, the last was help and documentation.

\section{RESULTS AND DISCUSSION}

In distributing questionnaires, this study uses a purposive sampling method [19] to get respondents. Which means, researchers first determine the conditions related to the intended respondent. The minimum requirements for being a respondent are Go-jek application users and at least they have used the application for a month, so we can check their experience using the application

Before the questionnaire was distributed, two tests were first carried out. Namely Test Validity by using a legibility test conducted by selecting ten prospective respondents randomly, to see to what extent the statements contained in the questionnaire can be understood by prospective respondents. Furthermore, the Reliability Test is carried out whether or not the draft questionnaire will be distributed reliably. In conducting Reliability Tests, use SPSS tools. Table 2 shows the results of the reliability test conducted, the test found that Cronbach's alpha was 0.873 which means that the statement was received. After the questionnaire is confirmed valid and reliable.

Table 1 Reliability Test of Questionnaire Instruments

\begin{tabular}{|c|c|c|}
\hline $\begin{array}{c}\text { Cronbach's } \\
\text { Alpha }\end{array}$ & $\begin{array}{c}\text { Cronbach's Alpha } \\
\text { Based on } \\
\text { Standardized Items }\end{array}$ & N of Items \\
\hline 0.861 & 0.873 & 10 \\
\hline
\end{tabular}

The next activity is distributing the list of question using interview approach to get responses from respondents who have been determined. From the results we get five person that want to be interviewed and we get the result. These five respondents will later be referred to as R1-R5. he five respondents were interviewed separately, and their opinions were asked regarding their experience in using the gojek application. Table 2 shows the checklist result from heuristic evaluation variable that have been distributed to the respondent.

\section{Variable}

\begin{tabular}{|l|l|c|c|c|c|c|}
\hline No & \multicolumn{1}{|c|}{$\begin{array}{c}\text { Heuristic } \\
\text { Evaluation } \\
\text { Variable }\end{array}$} & R1 & R2 & R3 & R4 & R5 \\
\hline 1 & $\begin{array}{l}\text { visibility of } \\
\text { system status }\end{array}$ & V & V & & V & V \\
\hline 2 & $\begin{array}{l}\text { match between } \\
\text { system and the } \\
\text { real world }\end{array}$ & $\mathrm{V}$ & $\mathrm{V}$ & $\mathrm{V}$ & $\mathrm{V}$ & $\mathrm{V}$ \\
\hline 3 & $\begin{array}{l}\text { user control and } \\
\text { freedom }\end{array}$ & & $\mathrm{V}$ & $\mathrm{V}$ & $\mathrm{V}$ & \\
\hline 4 & error prevention & $\mathrm{V}$ & $\mathrm{V}$ & & $\mathrm{V}$ & $\mathrm{V}$ \\
\hline 5 & $\begin{array}{l}\text { recognition } \\
\text { rather than } \\
\text { recall }\end{array}$ & $\mathrm{V}$ & $\mathrm{V}$ & $\mathrm{V}$ & $\mathrm{V}$ & $\mathrm{V}$ \\
\hline 6 & $\begin{array}{l}\text { flexibility and } \\
\text { efficiency of } \\
\text { use }\end{array}$ & $\mathrm{V}$ & $\mathrm{V}$ & $\mathrm{V}$ & $\mathrm{V}$ & $\mathrm{V}$ \\
\hline 7 & $\begin{array}{l}\text { aesthetic and } \\
\text { minimalist } \\
\text { design }\end{array}$ & $\mathrm{V}$ & $\mathrm{V}$ & $\mathrm{V}$ & $\mathrm{V}$ & $\mathrm{V}$ \\
\hline 8 & $\begin{array}{l}\text { help user } \\
\text { recognize- } \\
\text { diagnose- } \\
\text { recover from } \\
\text { errors }\end{array}$ & $\mathrm{V}$ & $\mathrm{V}$ & $\mathrm{V}$ & $\mathrm{V}$ & $\mathrm{V}$ \\
\hline 9 & $\begin{array}{l}\text { the last was } \\
\text { help and } \\
\text { documentation }\end{array}$ & $\mathrm{V}$ & $\mathrm{V}$ & & & $\mathrm{V}$ \\
\hline
\end{tabular}

From the interviewed process with five respondents, it was found that almost all respondents agreed that the Go-jek was superior in part of match between system and the real world. It means the Go-jek application is able to provide communicative images so that users can comfortably use their applications. Not only that, the color selection chosen by the go-jek application is also deemed appropriate, so users do not feel disturbed by the color choices that exist in the application. In the composition of the language used (terms used) in applications, it also tends to make it easier for users to understand and use existing features. The variable heuristic evaluation felt by the five respondents also represented the Go-jek application is recognition rather than recall, it shows that Go-jek application is quite good in choosing languages, symbols, and images. this is proven by the appearance of an error message if the server or application is being maintained by the center. even if this application releases the latest update, the user will be given a notification to update. this is felt by the user as one of the conveniences in using this application. The third is about the flexibility and efficiency of use. The five respondents agreed that this application was able to simplify and speed up users in carrying out any existing task. This is evidenced by the many features provided by Go-jek itself. As an example of Go-ride, Go-Car, even food delivery services can already be covered by this application. Fourth, aesthetic and minimalist design, the information submitted on this application is quite relevant. this is proven by the suitability of GPS tracking in this application. not only that, if there is a tenant from a restaurant partner for go-food that has changed, then the application will be as soon as possible to 
Gojek Terhadap Kepuasan Pelanggan Pada Mahasiswa/i Administrasi Niaga Politeknik Negeri Jakarta,” Epigram, vol. 13, no. 2, 2016.

[6] Z. Ebnehoseini, M. Tara, M. Meraji, K. Deldar, F. Khoshronezhad, and S. Khoshronezhad, "Usability evaluation of an admission, discharge, and transfer information system: a heuristic evaluation," Open access Maced. J. Med. Sci., vol. 6, no. 11, p. 1941, 2018 .

[7] A. Azizah and P. R. Adawia, "Analisis Perkembangan Industri Transportasi Online di Era Inovasi Disruptif (Studi Kasus PT Gojek Indonesia)," Cakrawala-Jurnal Hum., vol. 18, no. 2, pp. 149-156, 2018 .

[8] R. Khajouei, M. Zahiri Esfahani, and Y. Jahani, "Comparison of heuristic and cognitive walkthrough usability evaluation methods for evaluating health information systems," J. Am. Med. Informatics Assoc., vol. 24, no. e1, pp. e55-e60, 2017.

[9] B. Reeder, C. Drake, M. Ozkaynak, W. Jones, D. Mack, A. David, R. Starr, B. Trautner, and H. L. Wald, "Usability inspection of a mobile clinical decision support app and a short form heuristic evaluation checklist," in International Conference on HumanComputer Interaction, 2019, pp. 331-344.

[10] M. Murdiaty, A. Angela, and C. Sylvia, "Evaluasi Desain Antarmuka Portal Akademik Menggunakan Metode Heuristic Evaluation," J. Media Inform. Budidarma, vol. 3, no. 4, pp. 391-399, 2019.

[11] M. K. Othman, M. N. S. Sulaiman, and S. Aman, "Heuristic evaluation: comparing generic and specific usability heuristics for identification of usability problems in a living museum mobile guide app," Adv. Human-Computer Interact., vol. 2018, 2018.

[12] M. Huda, W. W. Winarno, and E. T. Lutfi, "Evaluasi User Interface Pada Sistem Informasi Akademik Di Stie Putra Bangsa Menggunakan Metode User Centered Systems Design,” J. Ekon. Dan Tek. Inform., vol. 5, no. 1, pp. 42-59, 2018.

[13] A. Ardiansyah and M. I. Ghazali, "Pengujian Usability User Interface dan User Experience Aplikasi E-Reader Skripsi Berbasis Hypertext,” J. Ilm. Teknol. Infomasi Terap., vol. 2, no. 3, 2016.

[14] H. Agustiyo, “Evaluasi Usability Aplikasi Pelayanan Masyarakat Jangka Joyoboyo Polres Kediri," in Proceeding Seminar Nasional Sistem Informasi dan Teknologi Informasi, 2018, vol. 1, no. 1, pp. 202-206.
[5] R. Rifaldi, K. Kadunci, and S. Sulistyowati, "Pengaruh Kualitas Pelayanan Transportasi Online 
[17] R. Yáñez Gómez, D. Cascado Caballero, and J.-L. Sevillano, "Heuristic evaluation on mobile interfaces: A new checklist,” Sci. World J., vol. 2014, 2014.

[18] G. F. Tondello, D. L. Kappen, E. D. Mekler, M. Ganaba, and L. E. Nacke, "Heuristic evaluation for gameful design," in Proceedings of the 2016 Annual Symposium on Computer-Human Interaction in Play Companion Extended Abstracts, 2016, pp. 315-323.

[19] H. M. Az-zahra, "Usability Evaluation of User Interface in Badan Narkotika Nasional East Java Province Website,” 2018 Int. Conf. Sustain. Inf. Eng. Technol., pp. 262-265, 2018. 